\title{
Author Correction: Loss of BCL9/9l suppresses Wht driven tumourigenesis in models that recapitulate human cancer
}

\author{
David M. Gay ${ }^{1}$, Rachel A. Ridgway, Miryam Müller, Michael C. Hodder', Ann Hedley', William Clark,

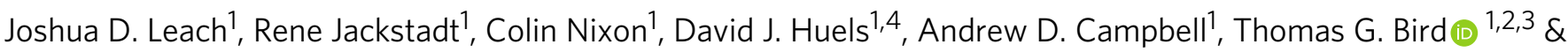 \\ Owen J. Sansom (i) ${ }^{1,2}$
}

Correction to: Nature Communications https://doi.org/10.1038/s41467-019-08586-3, published online 13 February 2019

The original version of this Article contained an error in the spelling of the author Miryam Müller, which was incorrectly given as Miryam Müeller. This has now been corrected in both the PDF and HTML versions of the Article.

Published online: 26 March 2019

\begin{abstract}
(c) (i) Open Access This article is licensed under a Creative Commons Attribution 4.0 International License, which permits use, sharing, adaptation, distribution and C. reproduction in any medium or format, as long as you give appropriate credit to the original author(s) and the source, provide a link to the Creative Commons license, and indicate if changes were made. The images or other third party material in this article are included in the article's Creative Commons license, unless indicated otherwise in a credit line to the material. If material is not included in the article's Creative Commons license and your intended use is not permitted by statutory regulation or exceeds the permitted use, you will need to obtain permission directly from the copyright holder. To view a copy of this license, visit http://creativecommons.org/licenses/by/4.0/.
\end{abstract}

(c) The Author(s) 2019

\footnotetext{
${ }^{1}$ Cancer Research UK Beatson Institute, Garscube Estate, Switchback Road, Glasgow G61 1BD, UK. ${ }^{2}$ Institute of Cancer Sciences, University of Glasgow, Garscube Estate, Glasgow G61 1QH, UK. ${ }^{3}$ MRC Centre for Inflammation Research, The Queen's Medical Research Institute, University of

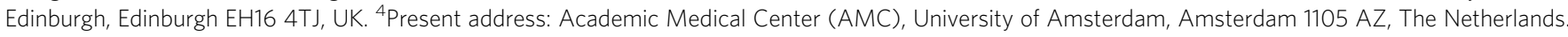
The original article can be found online at https://doi.org/10.1038/s41467-019-08586-3. Correspondence and requests for materials should be addressed to O.J.S. (email: o.sansom@beatson.gla.ac.uk)
} 